International Journal of Environment, Agriculture and Biotechnology
Vol-6, Issue-6; Nov-Dec, 2021
JJEAB
Journal Home Page Available: $\underline{\text { https://ijeab.com/ }}$
Journal DOI: $10.22161 /$ ijeab

\title{
Butterfly (Lepidoptera) Fauna of Krishnarajanagar Town, Mysore District, Karnataka
}

\author{
Nijagal B.S. , Hema K
}

PG Department of Zoology, JSS College of Arts, Commerce and Science, Ooty road, Mysuru, Karnataka. *Corresponding author

Received: 03 Oct 2021; Received in revised form: 15 Nov 2021; Accepted: 22 Nov 2021; Available online: 27 Nov 2021 (C)2021 The Author(s). Published by Infogain Publication. This is an open access article under the CC BY license (https://creativecommons.org/licenses/by/4.0/).

Abstract- A study was conducted to record the diversity of butterflies at Krishnarajanagara town of Mysore District over a period of six months from September 2019 to March 2020. Present survey was carried out in selected natural and man-made (parks) habitats of Krishnarajanagara town. A total of 1,147 individuals were recorded, photographed and identified which included 46 genera and 60 species belonging to five families. The relative abundance of butterflies of different families such as the Nymphalidae family was $43.33 \%$, followed by families Lycaenidae, Hesperidae, Pieridae and Papilionidae representing $18.33 \%, 15 \%, 13.33 \%$ and $10 \%$ in the study area respectively. Results indicated that Eurema hecabe was the most dominant species followed by Ypthima huebneri, Catopsilia ponoma, and Junonia lemonias in the study area. Dominance of these species can be explained by the presence of their larval and host plants in the study area.

Keywords-Butterfly, Man-made ecosystems, Pollard walk method.

\section{INTRODUCTION}

The butterflies are the most beautiful and colourful creatures on the earth and have high ecological significance as they are very good pollinators apart from honey bees. They are considered as good bio-indicators as they are sensitive to slightest variation in environment such as temperature, wind speed, rainfall, humidity and solar radiation (Murphy and Weiss, 1998; Sparrow et al., 1994; Spitzer et al., 1997; Brereton et al., 2011). Their distribution and abundance depends on different requirements for different habitat types for mating, breeding, and nectaring (Sprih Harsh, 2014). The present study aims to examine the distribution and abundance of butterflies across habitats studied. A checklist of butterfly species is also provided.

\section{MATERIALS AND METHODS}

\section{Study area}

Present study was carried out in selected Natural and Manmade ecosystems (parks) of Krishnarajanagara town, a taluk headquarters of Mysore district in the state of
Karnataka, Southern India. It is situated at an altitude of $12^{\circ} 26^{\prime} 21.8^{\prime \prime} \mathrm{N} 76^{\circ} 22^{\prime} 52.1^{\prime \prime E}$. Climate of the study area is tropical landscape. This implies that the winter and the early part of the summer are typically dry periods. The rainy season falls in between June and early October.

\section{Observation and identification of Butterflies}

Field observations were conducted twice a month from September 2019 to March 2020 for a period of seven months. Distribution and abundance of butterfly species were recorded in the study area by selecting Natural and Man-made ecosystems (parks) (Table.1). Observations were made through Pollard walk method (PWM) by counting all the butterflies found in 10 meter, beside the observer and and Direct Visual Count Method (DVCM) (Kunte, 1997; Gupta et al., 2012; Kunte et al., 2012). Butterflies were observed, captured, identified, photographed and released immediately to their natural habitat carefully. Care was taken not to damage physical parts of the butterflies. Photography was made by using Nikon D5600 (55-300mm 24.1MP) DSLR camera. 
The key characters used for identification were color pattern, wing span and mode of flight. Identifications were carried out with help of Evans (1932), Talbot (1947), Photographic guides of Smith (2006), Van der Poel \& Wangchuk (2007) and also using Photography and guidelines of The Book of Indian Butterflies (Isaac Kehimkar).

Table.1 Study sites with GPS location.

\begin{tabular}{|c|c|c|}
\hline Sites & Site name & GPS location \\
\hline S1 & H.B.C.S Layout & $12^{\circ} 25^{\prime} 53.2^{\prime \prime} \mathrm{N} 76^{\circ} 23^{\prime} 59.4^{\prime \prime} \mathrm{E}$ \\
\hline S2 & $\begin{array}{c}\text { Hale yadathore } \\
\text { Cauvery river }\end{array}$ & $12^{\circ} 28^{\prime} 03.0^{\prime \prime} \mathrm{N} 76^{\circ} 23^{\prime} 31.3^{\prime \prime} \mathrm{E}$ \\
\hline S3 & $\begin{array}{c}\text { Mahatma Gandhi } \\
\text { park }\end{array}$ & $12^{\circ} 26^{\prime} 19.4^{\prime \prime} \mathrm{N} 76^{\circ} 23^{\prime} 00.8^{\prime \prime} \mathrm{E}$ \\
\hline S4 & $\begin{array}{c}\text { Horticulture } \\
\text { Department garden }\end{array}$ & $12^{\circ} 25^{\prime} 19.1^{\prime \prime} \mathrm{N} 76^{\circ} 23^{\prime} 49.5^{\prime \prime} \mathrm{E}$ \\
\hline
\end{tabular}

\section{RESULT}

In the present study a total of 1,147 individual butterflies were recorded belonging to five families such as Nymphalidae, Pieridae, Lycaenidae, Papilionidae and Hesperidae with 46 genera and 60 species. Out of the five families recorded the relative abundance of Nymphalidae family is highest, representing $43.33 \%$ followed by families Lycaenidae, Hesperidae, Pieridae and Papilionidae representing 18.33\%, 15\%, $13.33 \%$ and $10 \%$ respectively (Fig.1). A checklist of species belonging to the five different families along with their status of occurrence in the study area is enlisted in Table 2.

Fig.2 depicts the relative abundance of butterfly species with respect to the total number of species recorded during the study period in each family. The relative abundance of Nymphalidae family was found to be $53.85 \%$ in site- $4,46.15 \%$ in site- 1 and 3 whereas in site- 2 it was $34.62 \%$. On the contrary, out of the total 8 species recorded in Pieridae family 7 species $(87.5 \%)$ were found in site-2 (Natural ecosystem) and 3 species (11.54\%) in site-4 (Manmade ecosystem) whereas the members of Hesperidae and Papilionidae families preferred site- 3 and site-4 (manmade ecosystems) as their relative abundance was high as compared to site- 1 and site-2. Of the 11 species recorded, the relative abundance of Lycaenid butterflies in site- 3 was found to be $63.64 \%$ ( 7 species) followed by site- 1 with $36.36 \%$ ( 4 Species) and site- 2 and site- 3 recorded $27.27 \%$ ( 3 species) each.
Monthly variations in the number of butterfly species of different families are shown in Fig.3. The graph clearly indicates that all the families encountered in the study area are available throughout the study period (September-2019 to March-2020). Nymphalidae family dominated in all the months with more than $40 \%$ of the total recorded. Members of Nymphalidae family were abundant during December when compared to other months. On the contrary, percent occurrence of Pieridae, Lycaenidae, Papilionidae and Hesperidae was found to be high during October, February, March and November respectively.

Based on the status of occurrence in the study area and availability during the study period, the butterfly species were categorized into very common (11 species), Common (17 species) and rare (32 species) (Table.1).

\section{DISCUSSION}

The study area may be favorable for better existence of butterfly community of Nymphalidae family as indicated by the results of the present study whereas the occurrence of Papilionidae in the study sites is comparatively less. The most plausible explanation would be habitat destruction due to urbanization which will be a threat to butterfly diversity. As a matter of fact, absence of food plants and nectar yielding plants in an area drives the butterfly population away due to the lack of feeding and breeding grounds. Anthropological interferences have an undeniably strong influence on the biodiversity of all existing species (Ricketts and Imhoff, 2003).

The study sites selected for the present study show variation in the abundance of butterfly species due to various factors, such as landscape, availability of host plants and most importantly anthropological disturbances. In the present study it may be noted that, Site- 3 and site- 4 were found to be rich in species diversity which had 31 and 28 species respectively with respect to total number of species recorded in the study area. Both the sites are manmade parks with large number of flowering plants. It is imperative that the richness in butterfly species diversity may depend on the type and variety of flowers and number of plants in a particular area and moreover the abundance, species richness and occurrence vary among different ecosystems. These results also indicate that, conservation of endemic species of butterflies may be possible by providing suitable environment to support the butterfly population and their survival (Myers et al., 2000).

Among the species recorded two species Pachliopta hector L and Hypolymnas misippus L have a protected status under the schedule I part IV of Indian Wildlife Protection act, 1972 (Aurora, 2003) and Lampides 
boeticus under Schedule IV (Gupta et. al., 2005). In the present study it can be observed that H.misippus and L.boeticus were found only in site-3 and 4 (Manmade ecosystem) which implies that conditions are suitable for their conservation in these sites, whereas $P$. hector was recorded in all the four sites. These observations throw light on the fact that the study area has favorable habitat and climate which influence distribution and abundance of butterflies (Wynter-Blyth, 1957). From the results of this study it may also be noted that the diversity and abundance of Lycaenidae family members is affected due to the absence of grass fields (Harisha and Hosetti, 2013).

The diversity, distribution and the abundance of butterflies recorded may vary according to season of the year which obviously depend on diversity and distribution of floral species and their blooming season. It may be mentioned that conservation of native flora and reduced human interference may have positive effect on the butterfly population and their survival (Myers et al., 2000).

Table:2 Checklist of the Butterflies and their occurrence in study area

\begin{tabular}{|c|c|c|c|c|c|c|c|c|}
\hline $\begin{array}{l}\text { Sl. } \\
\text { No }\end{array}$ & $\begin{array}{l}\text { Fam } \\
\text { ily }\end{array}$ & Common Name & Scientific Name & Site 1 & Site 2 & Site 3 & Site 4 & Status \\
\hline 1 & \multirow{23}{*}{ 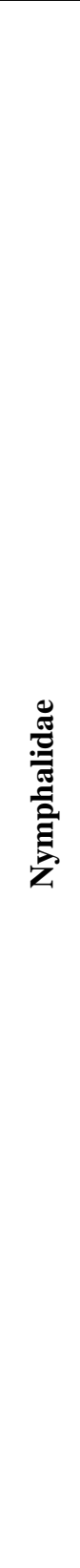 } & Common Four ring & Ypthima huebneri (Kirby,1871) & + & + & + & + & $\mathrm{VC}$ \\
\hline 2 & & Lemon pansy & Junonia lemonias (Linnaeus, 1758) & + & + & + & + & $\mathrm{VC}$ \\
\hline 3 & & Common crow & Euploea core (Cramer, 1780) & + & + & + & & $\mathrm{VC}$ \\
\hline 4 & & Tawny Castor & Acraea terpsicore (Linnaeus, 1758) & + & + & + & & $\mathrm{VC}$ \\
\hline 5 & & Blue tiger & Tirumala limniace (Cramer, 1775) & + & & & & $\mathrm{R}$ \\
\hline 6 & & Yellow pansy & Junonia hierta (Fabricius, 1798) & + & & & & $\mathrm{R}$ \\
\hline 7 & & Blue pansy & Junonia orithya (Linnaeus, 1764) & + & & + & & $\mathrm{C}$ \\
\hline 8 & & Dark blue tiger & Tirumala septentrionis (Butler,1874) & + & & & & $\mathrm{R}$ \\
\hline 9 & & Plain tiger & Danaus chrysippus (Linnaeus, 1758) & + & + & + & + & $\mathrm{VC}$ \\
\hline 10 & & Angled Castor & Ariadne ariadne (Linnaeus, 1763) & + & & & & $\mathrm{R}$ \\
\hline 11 & & Grey Pansy & Junonia atlites (Linnaeus, 1763) & & & + & + & $\mathrm{C}$ \\
\hline 12 & & Peacock Pansy & Junonia almania (Linnaeus, 1758) & & + & & & $\mathrm{R}$ \\
\hline 13 & & Chocolate Pansy & Junonia iphita (Cramer, 1779) & & & + & + & $\mathrm{C}$ \\
\hline 14 & & Painted lady & Vanessa cardui (Linnaeus, 1758) & & & + & & $\mathrm{R}$ \\
\hline 15 & & Great Egg fly & Hypolimnas bolina (Linnaeus, 1758) & & & + & + & $\mathrm{C}$ \\
\hline 16 & & Danaid Egg fly & $\begin{array}{l}\text { Hypolimnas misippus } \\
\text { (Linnaeus,1758) }\end{array}$ & & & + & + & $\mathrm{C}$ \\
\hline 17 & & $\begin{array}{l}\text { Dark Evening } \\
\text { Brown }\end{array}$ & Melanitis phedima (Cramer, 1780) & & & & + & $\mathrm{R}$ \\
\hline 18 & & Common Castor & Ariadne merione (Cramer, 1777) & & + & & + & $\mathrm{C}$ \\
\hline 19 & & Common Baron & Euthalia aconthea (Cramer, 1777) & & & + & + & $\mathrm{C}$ \\
\hline 20 & & $\begin{array}{l}\text { Common Evening } \\
\text { Brown }\end{array}$ & Melanitis leda (Linnaeus, 1758) & & & & + & $\mathrm{R}$ \\
\hline 21 & & Striped Tiger & Danaus genutia (Cramer, 1779) & + & & & + & $\mathrm{C}$ \\
\hline 22 & & $\begin{array}{l}\text { Common Bush } \\
\text { Brown }\end{array}$ & Mycalesis perseus (Fabricius, 1775) & + & & & & $\mathrm{R}$ \\
\hline 23 & & Joker & Byblia ilithyia (Drury, 1773) & & + & & & $\mathrm{R}$ \\
\hline
\end{tabular}




\begin{tabular}{|c|c|c|c|c|c|c|c|c|}
\hline 24 & & Medus Brown & Orsotriaena medus (Moore, 1858) & & + & & & $\mathrm{R}$ \\
\hline 25 & & Tailed Palm Fly & Elymnias caudata (Butler, 1871) & & & & + & $\mathrm{R}$ \\
\hline 26 & & Common Sailor & Neptis hylas (Linnaeus, 1758) & & & & + & $\mathrm{R}$ \\
\hline 27 & \multirow{8}{*}{ } & Common emigrant & Catopsilia pomona (Fabricius, 1775 ) & + & + & + & + & $\mathrm{VC}$ \\
\hline 28 & & $\begin{array}{l}\text { Common grass } \\
\text { yellow }\end{array}$ & Eurema hecabe (Linnaeus, 1758) & + & + & + & + & VC \\
\hline 29 & & Plain Orange Tip & Colotis aurora (Cramer, 1780) & + & & & & $\mathrm{R}$ \\
\hline 30 & & Mottled emigrant & Catopsilia pyranthe (Linnaeus, 1758) & + & + & + & & $\mathrm{VC}$ \\
\hline 31 & & Crimson tip & Colotis danae (Linnaeus, 1787) & & + & & & $\mathrm{R}$ \\
\hline 32 & & Common jezebel & Delias eucharis (Drury, 1773) & & + & + & & $\mathrm{C}$ \\
\hline 33 & & Small Grass Yellow & Eurema brigitta (Cramer, 1780) & & + & & & $\mathrm{R}$ \\
\hline 34 & & Psyche & Leptosia nina (Fabricius, 1793) & & & & + & $\mathrm{R}$ \\
\hline
\end{tabular}

\begin{tabular}{|c|c|c|c|c|c|c|c|c|}
\hline 35 & \multirow{11}{*}{ 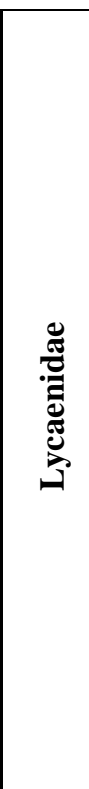 } & Gran blue & Euchrysops cnejus (Fabricius, 1798) & + & & & & $\mathrm{R}$ \\
\hline 36 & & $\begin{array}{l}\text { Common Silver } \\
\text { Line }\end{array}$ & Cigaritis vulcanus (Fabricius, 1775) & + & & & & $\mathrm{R}$ \\
\hline 37 & & Common Cerulean & Jamides celeno (Cramer, 1779) & + & & + & & $\mathrm{C}$ \\
\hline 38 & & Pea Blue & Lampides boeticus (Linnaeus, 1767 ) & + & + & + & + & $\mathrm{VC}$ \\
\hline 39 & & Plains Cupid & Luthrodes pandava (Horsfield, 1829) & & & + & & $\overline{\mathrm{R}}$ \\
\hline 40 & & Dark grass blue & Zizeeria karsandra (Moore, 1865) & & & + & & $\overline{\mathrm{R}}$ \\
\hline 41 & & Pale grass blue & Pseudozizeeria maha (Kollar, 1844) & & & & + & $\mathrm{R}$ \\
\hline 42 & & Lesser Grass Blue & Zizina otis (Fabricius, 1787) & & + & + & & $\mathrm{C}$ \\
\hline 43 & & $\begin{array}{l}\text { Common hedge } \\
\text { blue }\end{array}$ & Acytolepis puspa (Horsfield, 1828) & & + & & + & $\mathrm{C}$ \\
\hline 44 & & Common Line blue & Prosotas nora (R. Felder,1860) & & & + & & $\mathrm{R}$ \\
\hline 45 & & Zebra Blue & Leptotes plinius (Fabricius, 1793) & & & + & & $\bar{R}$ \\
\hline 46 & \multirow{6}{*}{ 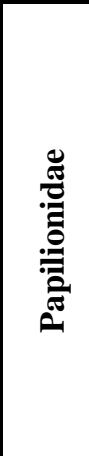 } & Common Mormon & Papilio polytes (Linnaeus, 1758) & + & + & + & + & $\mathrm{VC}$ \\
\hline 47 & & Common Rose & $\begin{array}{l}\text { Pachliopta aristolochiae (Fabricius, } \\
\text { 1775) }\end{array}$ & + & + & + & + & $\mathrm{VC}$ \\
\hline 48 & & Lime Butterfly & Papilio demoleus (Linnaeus, 1758) & & + & + & & $\mathrm{C}$ \\
\hline 49 & & Crimson Rose & Pachliopta hector (Fabricius, 1758) & & & + & + & $\mathrm{C}$ \\
\hline 50 & & Blue Mormon & Papilio polymnestor (Cramer, 1775) & & & + & + & $\mathrm{C}$ \\
\hline 51 & & Tailed Jay & $\begin{array}{l}\text { Graphium Agamemnon (Fabricius, } \\
\text { 1864) }\end{array}$ & & & & + & $\mathrm{R}$ \\
\hline 52 & \multirow{4}{*}{$\begin{array}{l}\text { Hes } \\
\text { peri } \\
\text { idae }\end{array}$} & Dark Palm Dart & Telicota bambusae (Moore, 1878) & + & + & & & $\mathrm{C}$ \\
\hline 53 & & $\begin{array}{l}\text { Asian Grizzled } \\
\text { Skipper }\end{array}$ & Spialia galba (Fabricius, 1793) & & + & & + & $\mathrm{C}$ \\
\hline 54 & & Marbled Skipper & Gomalia elma (Trimen, 1862) & & + & & & $\bar{R}$ \\
\hline 55 & & $\begin{array}{l}\text { Rounded Palm- } \\
\text { Red Eye }\end{array}$ & Erionota torus (Evans, 1941) & & & + & & $\mathrm{R}$ \\
\hline
\end{tabular}




\begin{tabular}{|c|c|c|c|c|c|c|}
\hline 56 & $\begin{array}{l}\text { Common Banded } \\
\text { Awl }\end{array}$ & Hasora chromus (Cramer 1780) & & + & & $\mathrm{R}$ \\
\hline 57 & Grass Dart & $\begin{array}{l}\text { Taractrocera maevius (Fabricius, } \\
\mathbf{1 7 9 3 )}\end{array}$ & & + & & $\mathrm{R}$ \\
\hline 58 & Grass Demon & Udaspes folus (Cramer, 1775) & & & + & $\mathrm{R}$ \\
\hline 59 & Rice Swift & Borbo cinnara (Wallace, 1866$)$ & + & & & $\mathrm{R}$ \\
\hline 60 & Chestnut Bob & Iambrix salsala (Moore, 1866) & & & + & $\mathrm{R}$ \\
\hline
\end{tabular}

Status: VC- Very common, C- Common, R- Rare

Fig. 1 Relative abundance of Butterfly families in the study area

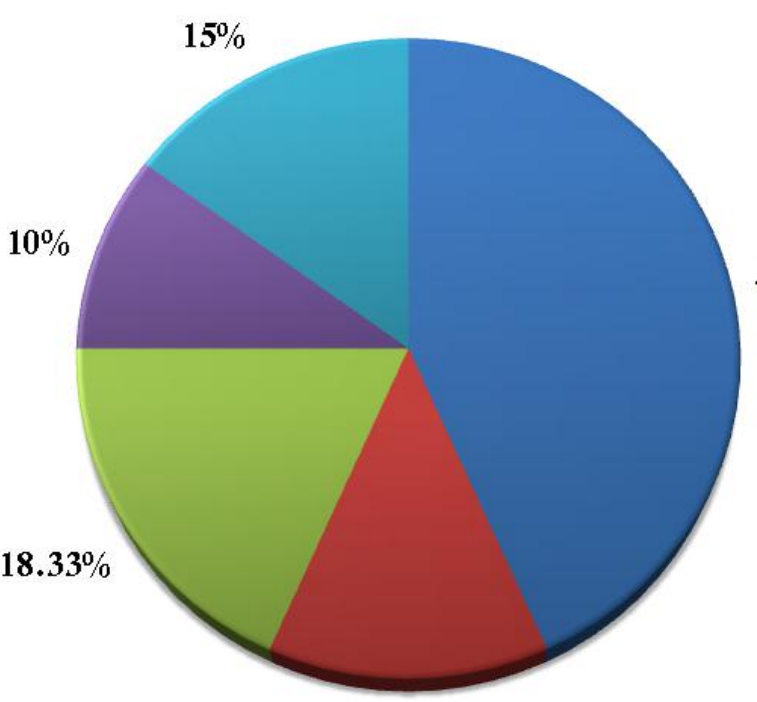

$13.33 \%$
$43.33 \%$

Nymphalidae

口ieridae

$\square$ Lycaenidae

$\square$ Papilionidae

$\square$ Hesperiidae

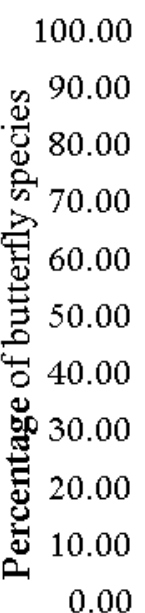

0.00

Fig. 2 Percent occurence of butterfly species in different study sites

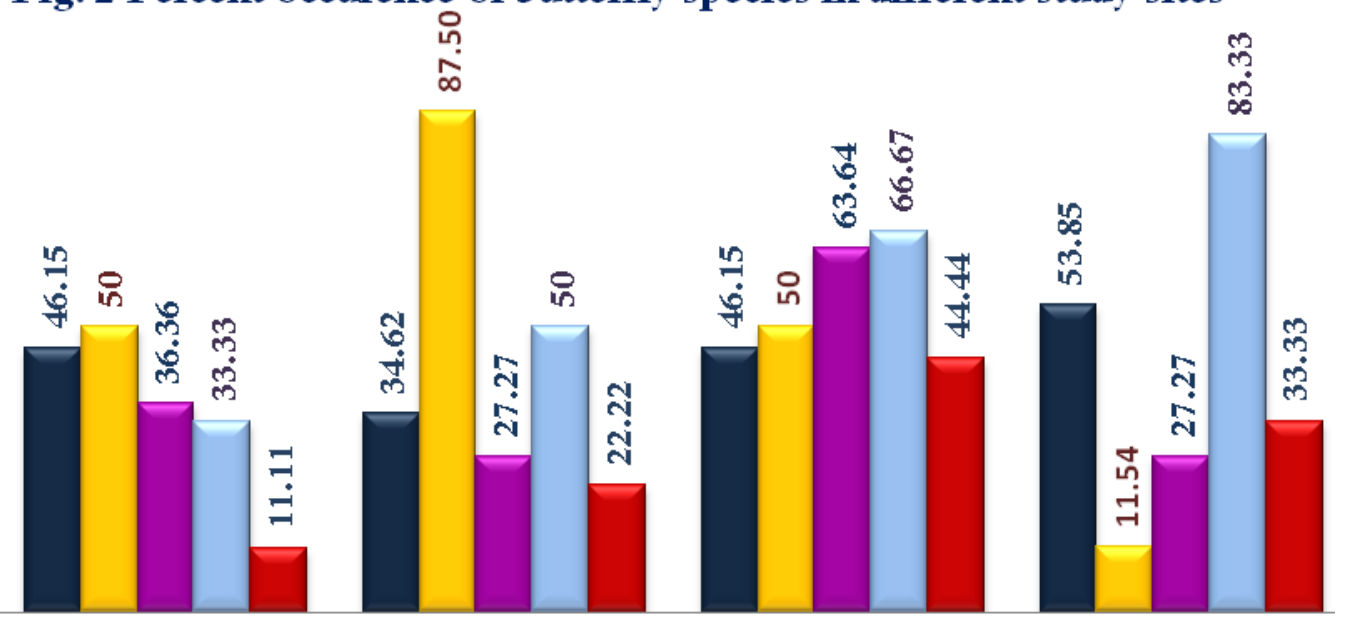

Site 1

Site 2

Site 3

Site 4

$\square$ Nymphalidae $\square$ Pieridae $\square$ Lycaenidae $\square$ Papilionidae $\square$ Hesperiidae 
Fig.3 Monthly variation in the percent availabilty of butterfly families in the study

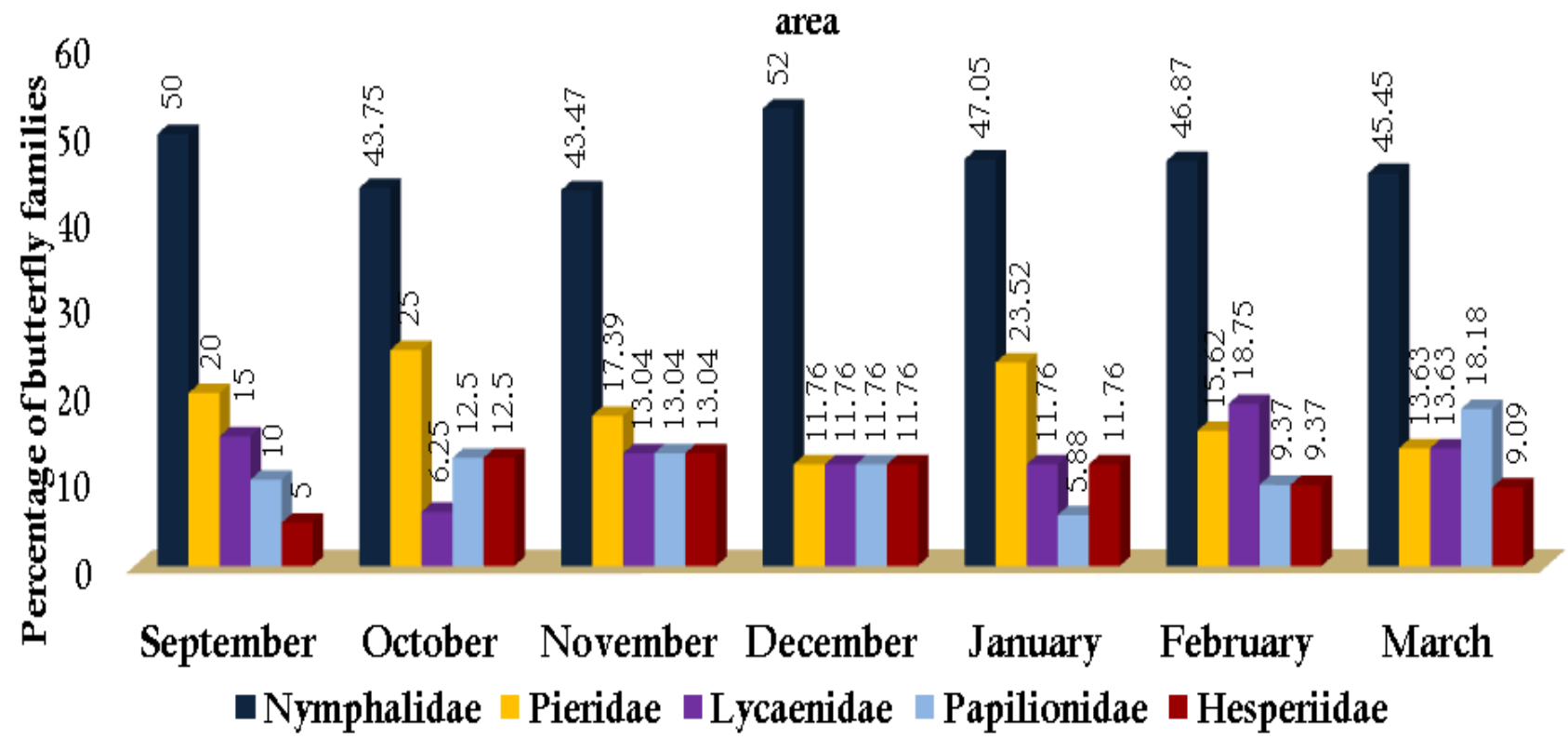

Plate.1 Butterflies of Nymphalidae family recorded in the study area

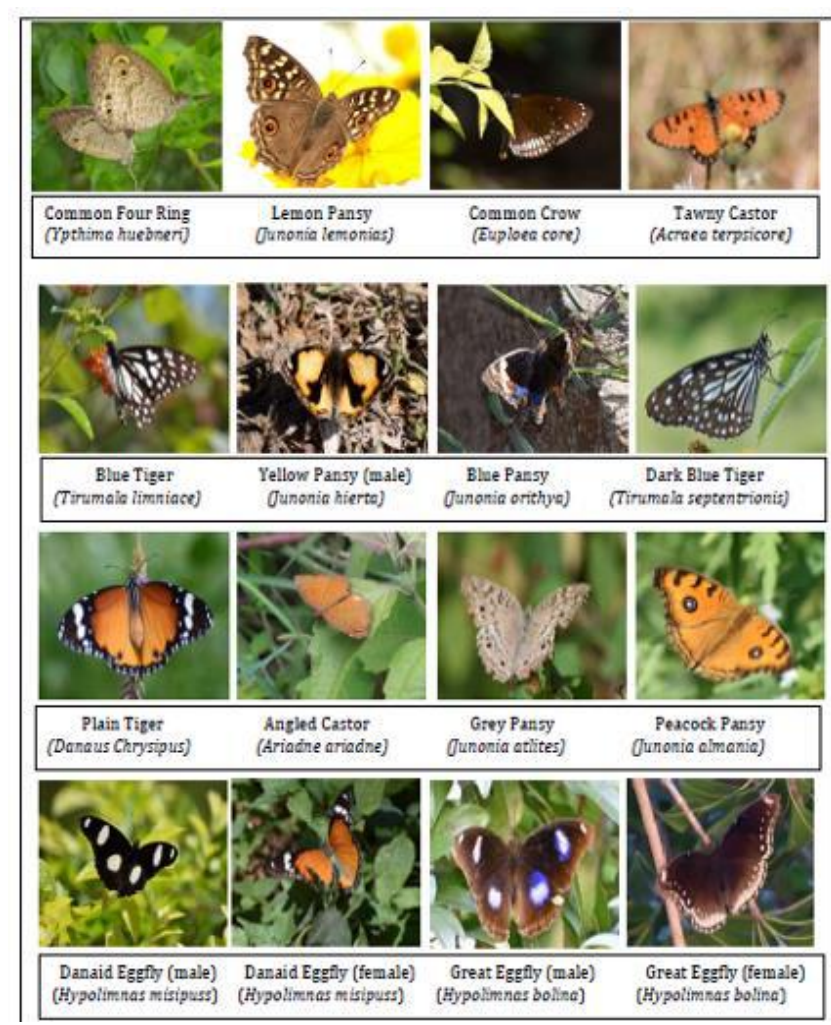

A

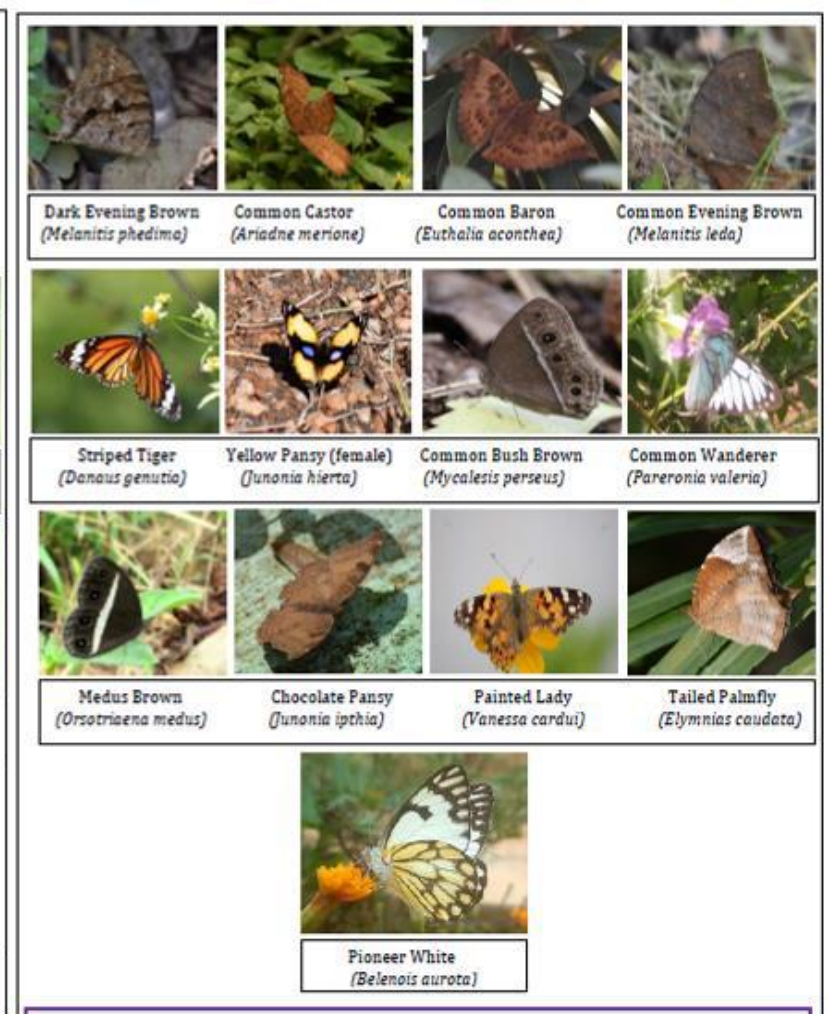

B 
Plate-2 Butterflies of Pieridae (C) and Lycaenidae (D) families recorded in the study area

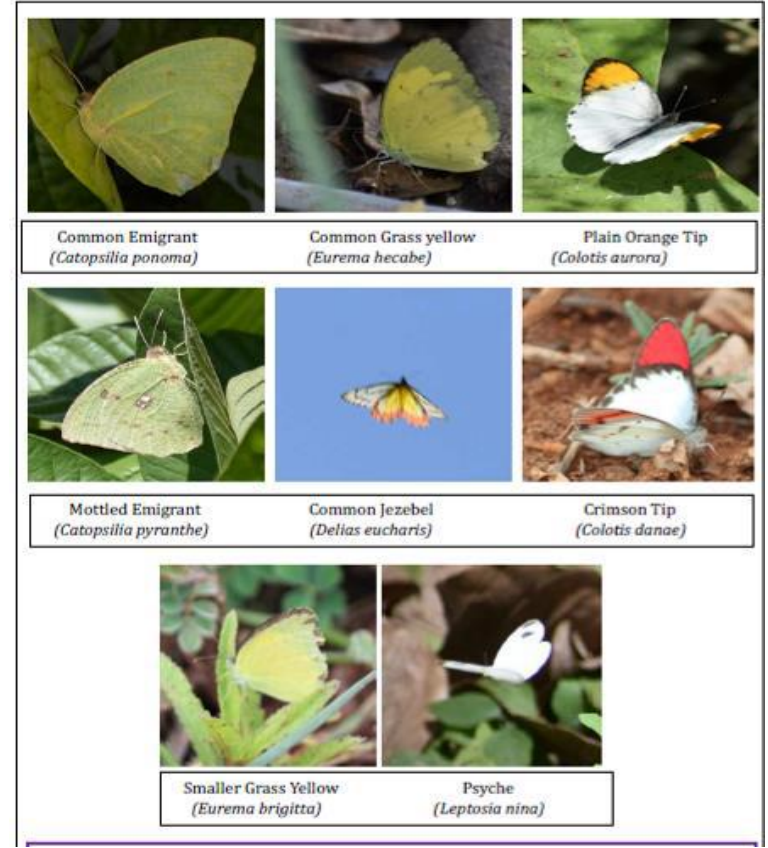

$\mathbf{C}$
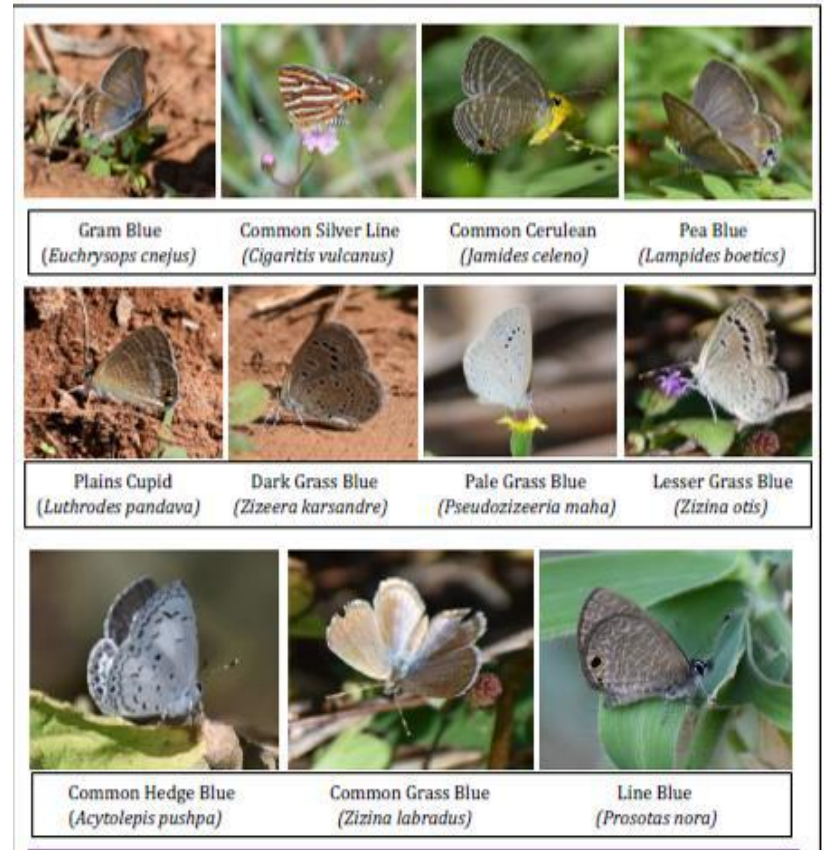

D

Plate.3 Butterflies of Papilionidae $(E)$ and Hesperiidae $(F)$ families recorded in the study area

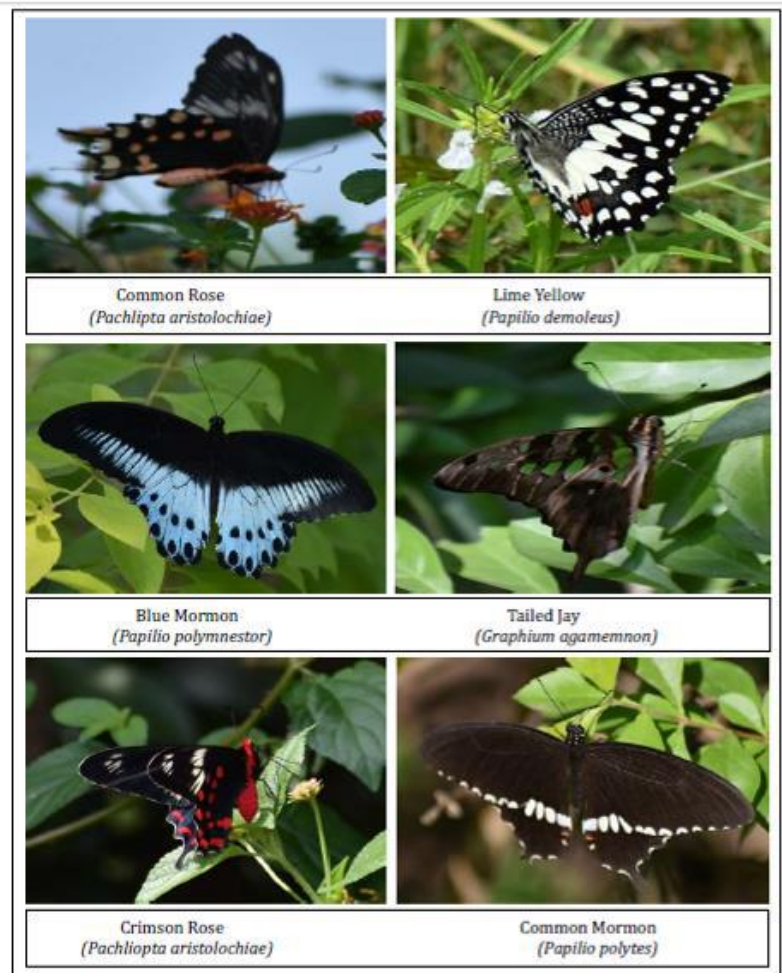

$\mathbf{E}$

\section{REFERENCES}

[1] Aurora, K. (2003). Forest Laws. The Wildlife Protection Act, 1972 as amended by the Wild (Protection) Amendment Act, 2002. Professional Book Publishers, New Delhi, 85pp.

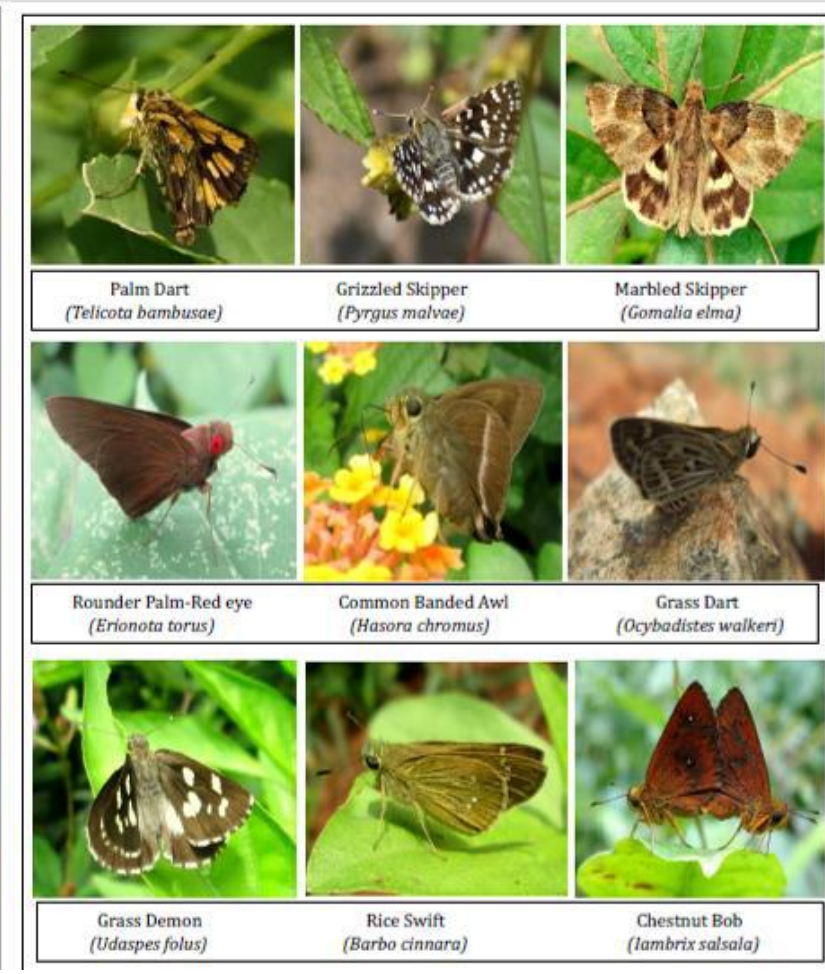

$\mathbf{F}$

[2] Brereton T., D. B. Roy, I. Middlebrook, M. Botham, and M. Warren, (2011) "The development of butterfly indicators in the United Kingdom and assessments in 2010," Journal of Insect Conservation, vol. 15, no. 1, pp. 139-151. 
[3] Evans, W.H. (1932). The identification of Indian Butterflies, 2nd Edition, Natural History Society, Bombay, India.

[4] Gupta, M.B., Rao, P.V.S., Reddy, D.S., Maddala, S.R.S.C.S. and Babu, P.M. (2012). A Preliminary Observations on Butterflies of Seshachalam Biosphere reservoir, Eastern Ghats, Andhra Pradesh, India, World Journal of Zoology, 7(1): 83-89.

[5] Harisha M.N., B.B. Hosetti (2013) Butterfly fauna of Daroji Sloth Bear Sanctuary, Hospet, Bellary District, Karnataka Journal of Research in Biology 3 (2), 840-846

[6] Kunte, K. (1997). Seasonal patterns in butterfly abundance and species diversity in four tropical habitats in Northern Western Ghats, Journal of Biosciences, 22: 593-603.

[7] Kunte, K., Sondhi, S., Sangam, B.M., Lovalekar, R., Tokekar, K. and Agarvekar, G. (2012). Butterflies of Garo Hills of Meghalaya, Northeastern India: their diversity and conservation, Journal of Threatened Taxa, 4(10): 2933 2992.

[8] Murphy D.D.and S.B.Weiss, (1988) “A long-term monitoring plan for a threatened butterfly," Conservation Biology, vol. 2, pp. 367-374,.

[9] Myers, N., Russell, A., Mittermelert, C., Mittermelert, G., Gustavo, A. B. and Fonseca, K. J. (2000), Biodiversity hotspots for conservation priorities. Nature, 403, 853- 858.

[10] Smith, C. (2006). Illustrated Checklist of Nepal's Butterflies. Craftsman Press, Bangkok.

[11] Sparrow H.R, T.D.Sisk, P.R.Ehrlich, and D.D.Murphy, (1994) "Techniques and guidelines for monitoring neotropical butterflies," Conservation Biology, vol. 8, no. 3, pp. 800-809.

[12] Spitzer, K.. J. Jaro`s, J. Havelka, and J. Lep`s, (1997) "Effect of smallscale disturbance on butterfly communities of an Indochinese montane rainforest," Biological Conservation, vol. 80, no. 1, pp.9-15.

[13] Sprih Harsh, (2014) "Butterfly Diversity of Indian Institute of Forest Management, Bhopal, Madhya Pradesh, India" Journal of Insects, Vol 2014, Art. ID 254972.

[14] Talbot, G.(1947). The Fauna of British India including Ceylon and Burma butterflies, 2nd Edition, Volume-II, Taylor and Francis Ltd., London, UK.

[15] Van der Poel, P. and T. Wangchuk. (2007). Butterflies of Bhutan Mountains, hills and valleys between 800 and $3000 \mathrm{~m}$. Royal Society for Protection of Nature (RSPN), Thimphy, Bhutan. 